Environ. Control in Biol., 11, 55-63, 1973

\title{
FEEDBACK CONTROL OF LEAF TEMPERATURE
}

\author{
Tsuyoshi Matsur and Hiromi Eguchi \\ Biotron Institute, Kyushu University, Fukuoka, Japan
}

(Received March 21, 1973)

To control the leaf temperature by means of setting the desired value of the leaf temperature, the feedback control of leaf temperature was carried out in a growth cabinet: The leaf temperature was detected by the use of a microthermistor which was inserted into the cotyledon of the Cucurbita seedling. This leaf temperature was used as the feedback signal for the temperature control system in the growth cabinet. In this system, air was used for heat transfer, and the program control of the leaf temperature was made possible by setting the desired value.

For the analyses of the response characteristics in the leaf temperature control, conditions of light, air humidity and air movement were changed to give the disturbances to the leaf temperature control.

From the results, the following points were ascertained.

1) In this system, the ramp response in the feedback control of the leaf temperature conformed well to the desired value. At the leaf temperatures of $10^{\circ} \mathrm{C}$, there was no difference between the leaf and air temperature in darkness. With the increased temperature, however, the air temperature became higher than the leaf temperature.

2) When the leaf was irradiated to an intensity of $31 \mathrm{~mW} / \mathrm{cm}^{2}$ by an incandescent lamp, the leaf temperature rose, while the air temperature fell. In proportion to this fall in air temperature, the leaf temperature settled within at least $15 \mathrm{~min}$. The effect of this disturbance of irradiation on the leaf temperature control was larger in lower temperature condition than in higher temperature condition.

3) When the air humidity was changed rapidly from $60 \%$ to $80 \%$ and from $80 \%$ to $40 \%$, the leaf temperature control was disturbed. The effect of the air humidity change on the leaf temperature control was larger under higher temperature condition than under lower temperature condition. The leaf temperature settled within $10 \mathrm{~min}$.

4) The air movement decreased the difference between the leaf and air temperatures and made the settling time short.

It is known that the plant temperature is different from the ambient air temperature, ${ }^{1,2,6,7)}$ and we reported in previous papers that the leaf temperature is remarkably affected by environmental factors such as air temperature, light, air humidity and air movement. ${ }^{4,5}$ ) However, only the air temperature is controlled in the temperature controlled room, and little attention has been paid to the plant temperature which seems to be mainly responsible for various physiological functions. Thus, much more importance must be attached to the plant temperature for the exact analysis of the effect of temperature on plant responses. From this viewpoint, it is necessary to set the desired value of the leaf temperature in the temperature control system.

Present report deals with the feedback control of leaf temperature in a growth cabinet; the leaf temperature is used as the feedback signal in the temper- 
ature control system, in order to make it possible to set directly the desired value of the leaf temperature in the program controller, and the characteristics of this control system were analyzed.

\section{MATERIALS AND METHODS}

Plant material. Seeds of Cucurbita maxima Duch. "Tokyo-wase" were sown in plastic pots filled with burnt chaff (charcoal of chaff) which was used as the root supporter. The perforated bottom of the pot was kept soaked in water to moisten the burnt chaff. Five days after germination, the cotyledon was used for this experiment.

Growth cabinet. In the growth cabinet ${ }^{3)}$ used, the refrigerators were continuously operated, and the PID action was adapted for feedback control of temperature; the capacity of the electric heater was regulated by PID action. This growth cabinet has the capacity to control the air temperature within a range of $-5^{\circ} \mathrm{C}$ to $40^{\circ} \mathrm{C}$ with an accuracy of $\pm 0.5^{\circ} \mathrm{C}$ and to control the relative humidity within the range of $20 \%$ to $90 \% \pm 3 \%$ at air temperatures of $10^{\circ} \mathrm{C}$ to $40^{\circ} \mathrm{C}$. The lateral velocity of air movement was controlled by changing the rpm of a fan installed in the growth cabinet. For irradiation, an incandescent lamp (Toshiba $500 \mathrm{~W}$ photographic lamp) was used.

Test procedure. Figure 1 shows the feedback-control system of leaf temperature. The leaf temperature was detected by means of a microthermistor (Hypodermic probe, Y.S.I. Co., USA) which was inserted into the cotyledon of the Cucurbita seedling. With this thermometer, the leaf temperature can be measured to an accuracy of $\pm 0.3^{\circ} \mathrm{C}$ and a time constant of $0.6 \mathrm{sec}$. The detected signal of the leaf temperature was led into a bridge box and exchanged into voltage of $10 \mathrm{mV}$ D.C. at $50^{\circ} \mathrm{C}$ and $0 \mathrm{mV}$ D.C. at $-10^{\circ} \mathrm{C}$. This temperature signal was led into PID controller to use as the feedback signal, and at the same time, recorded as temperature value by the electronic self balancing recorder. In this system, the air is used for heat transfer, and the leaf temperature can be controlled by setting the desired value in the program controller.

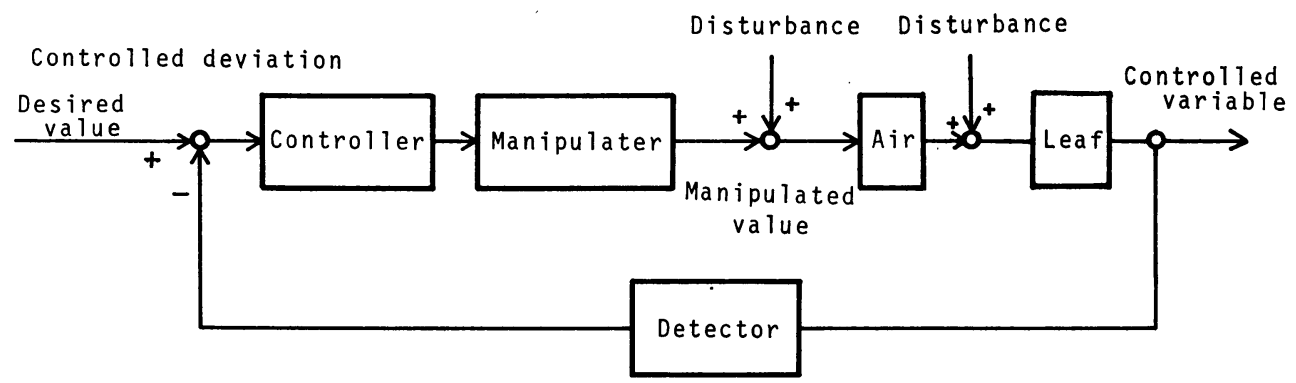

Fig. 1 Block diagram of feedback control system of leaf temperature.

To analyze the response characteristics in the leaf temperature control, various conditions of light, air humidity and air movement velocity were given as the disturbances to the leaf temperature control system.

\section{RESULTS AND DISCUSSION}

Figure 2 shows the ramp response in feedback control of the leaf temperature 


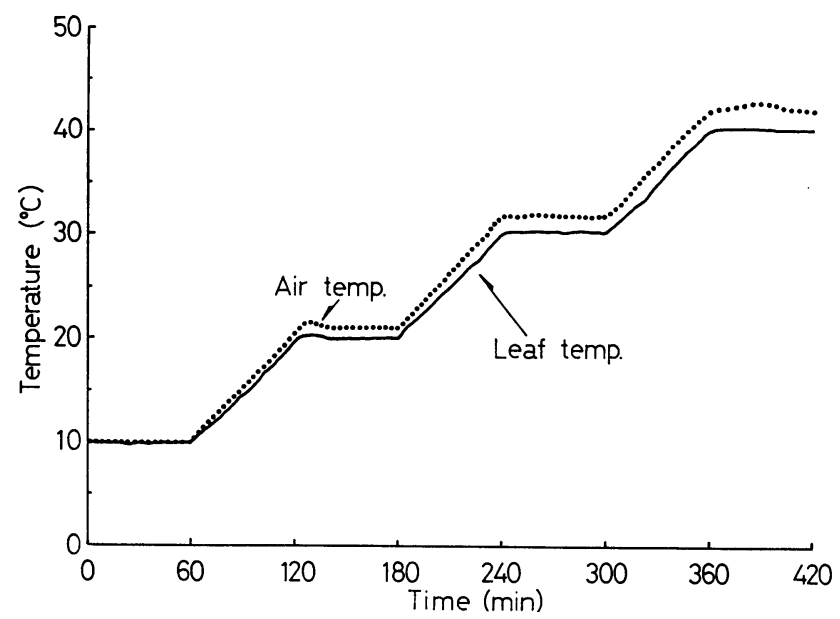

Fig. 2 Ramp response in program control of leaf temperature under the relative humidity of $60 \%$ in darkness.

at air humidity of $60 \%(\mathrm{RH})$ and air movement of $0.3 \pm 0.2 \mathrm{~m} / \mathrm{sec}$ in darkness. The leaf temperature conformed well to the desired value. At a leaf temperature of $10^{\circ} \mathrm{C}$, there is no difference between the leaf and air temperatures. With the increased temperature of the leaf, however, the air temperature became higher than the leaf temperature, and at the leaf temperature of $40^{\circ} \mathrm{C}$, the difference between the leaf and air temperatures was $3^{\circ} \mathrm{C}$. Thus, program control of the leaf temperature was made possible by this system.

To analyze the effects of the disturbances on the leaf temperatures in the constant-value control, the leaf was irradiated vertically to an intensity of $31 \mathrm{~mW} /$ $\mathrm{cm}^{2}$ by an incandescent lamp, and the air humidity was rapidly changed from $60 \%$ to $80 \%$ and also from $80 \%$ to $40 \%$ by the step input, at the constant leaf temperatures of 20,30 and $40^{\circ} \mathrm{C}$, respectively. Further, the lateral velocity of air movement was changed by a fan.

Figure 3 shows the effects of light and air humidity on the leaf temperature controlled at the desired value of $20^{\circ} \mathrm{C}$ with an air movement of $0.3 \pm 0.2 \mathrm{~m} / \mathrm{sec}$. In darkness, the leaf temperature was $20^{\circ} \mathrm{C}$ and air temperature was $20.8^{\circ} \mathrm{C}$ at air humidity of $60 \%$. When the leaf was irradiated, the leaf temperature rose rapidly, while, the air temperature started to fall after the dead time of about $20 \mathrm{sec}$ and became $12.0^{\circ} \mathrm{C}$ at its minimum. The leaf temperature became $23.5^{\circ} \mathrm{C}$ at its maximum, and thereafter fell gradually to $19^{\circ} \mathrm{C}$ within $10 \mathrm{~min}$, in proportion to the air temperature fall. In a few minutes, the air temperature gradually rose to $13.2^{\circ} \mathrm{C}$ and the leaf temperature settled at the desired value of $20^{\circ} \mathrm{C}$. The settling time of the leaf temperature was about $15 \mathrm{~min}$. Maximal difference between the leaf and air temperatures was $7^{\circ} \mathrm{C}$ during irradiation. When the irradiation was stopped, the leaf temperature rapidly fell to $16.8^{\circ} \mathrm{C}$. While, the air temperature started to rise after the dead time of about $20 \mathrm{sec}$ and became $21.5^{\circ} \mathrm{C}$ at its maximum, thereafter it gradually fell to $20.7^{\circ} \mathrm{C}$. Then, the leaf temperature which was at its minimum temperature rose and settled to the desired value, in proportion to the air temperature rise. The settling time was $6 \mathrm{~min}$. When the 

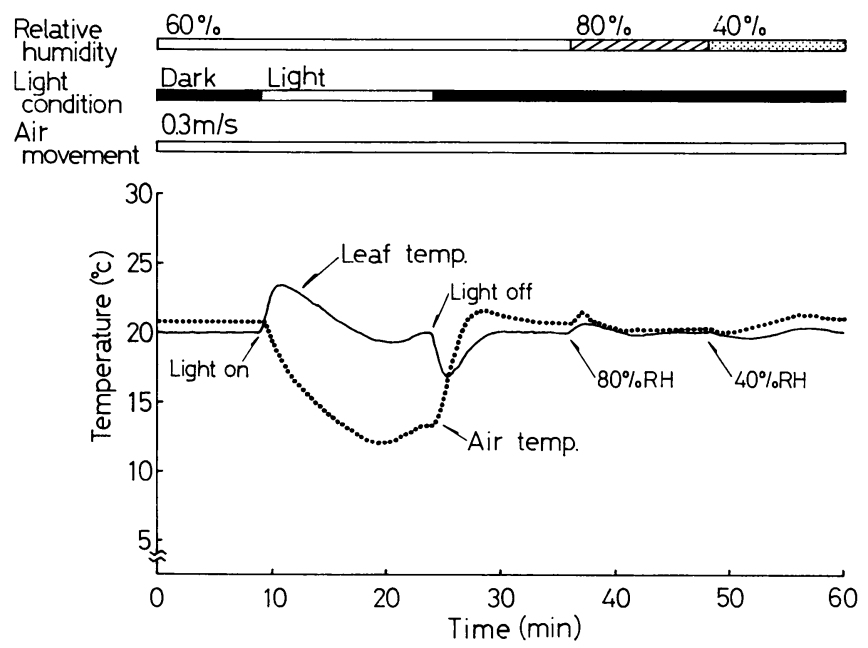

Fig. 3 Effects of light and air humidity on the control of leaf temperature at $20^{\circ} \mathrm{C}$ with an air velocity of $0.3 \mathrm{~m} / \mathrm{sec}$.

air humidity was changed from $60 \%$ to $80 \%$, both the air and leaf temperatures rose slightly. This air temperature rise can be considered to have been caused by steam supplied to increase the air humidity in the growth cabinet. The air temperature fell immediately and the leaf temperature settled within $4 \mathrm{~min}$. The difference between the leaf and air temperatures was $0.3^{\circ} \mathrm{C}$. When the air humidity of $80 \%$ was decreased to $40 \%$, the leaf temperature fell to $19.5^{\circ} \mathrm{C}$ and settled to the desired value after $6 \mathrm{~min}$, in proportion to the air temperature rise. The difference between the leaf and air temperatures became greater than that at the air humidity of $80 \%$ and was $1.3^{\circ} \mathrm{C}$ at its maximum.

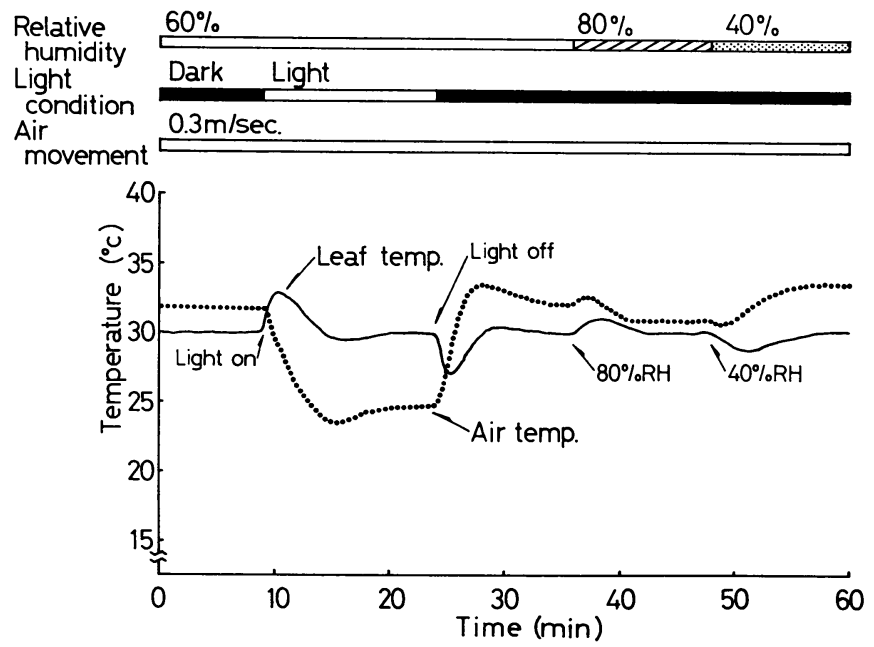

Fig. 4 Effects of light and air humidity on the control of leaf temperature at $30^{\circ} \mathrm{C}$ with an air velocity of $0.3 \mathrm{~m} / \mathrm{sec}$. 
Figure 4 shows the effects of light and air humidity on the leaf temperature controlled at $30^{\circ} \mathrm{C}$ with an air movement of $0.3 \pm 0.2 \mathrm{~m} / \mathrm{sec}$. In darkness, the leaf temperature was $30^{\circ} \mathrm{C}$ and the air temperature was $31.8^{\circ} \mathrm{C}$ at air humidity of $60 \%$. When the leaf was irradiated, the leaf temperature rose to $32.9^{\circ} \mathrm{C}$ at its maximum, while, the air temperature started to fall after the dead time of about $20 \mathrm{sec}$ and became $23.5^{\circ} \mathrm{C}$ at its minimum, thereafter, gradually settling to $24.8^{\circ} \mathrm{C}$. In proportion to this fall in the air temperature, the leaf temperature fell and settled within $11 \mathrm{~min}$. When irradiation ceased, the leaf temperature fell rapidly to $27.0^{\circ} \mathrm{C}$ at its minimum, while, the air temperature started to rise after the dead time of about $20 \mathrm{sec}$ and became $33.3^{\circ} \mathrm{C}$ at its maximum. Then the leaf temperature settled within $9 \mathrm{~min}$. When the air humidity of $60 \%$ was increased to $80 \%$, both the air and leaf temperatures rose slightly. Thereafter the air temperature fell to 31.0 and the leaf temperature settled within $3 \mathrm{~min}$. When the air humidity of $80 \%$ was decreased to $40 \%$, the leaf temperature fell to $28.5^{\circ} \mathrm{C}$, while, the air temperature rose to $33.5^{\circ} \mathrm{C}$. In proportion to the air temperature rise, the leaf temperature settled within 9 min.

Figure 5 shows the effects of light and air humidity on the leaf temperature controlled at $40^{\circ} \mathrm{C}$ with an air movement of $0.3 \pm 0.2 \mathrm{~m} / \mathrm{sec}$. In darkness, the leaf temperature was $40^{\circ} \mathrm{C}$ and the air temperature was $42^{\circ} \mathrm{C}$ at air humidity of $60 \%$. When the leaf was irradiated, the leaf temperature rose to $42.9^{\circ} \mathrm{C}$ at its maximum. While, the air temperature started to fall after the dead time of about $20 \mathrm{sec}$ and became $36.4^{\circ} \mathrm{C}$ at its minimum. In proportion to the air temperature fall, the leaf temperature fell and settled within $6 \mathrm{~min}$. When irradiation ceased, the leaf temperature fell to $37.5^{\circ} \mathrm{C}$ at its minimum, while, the air temperature started to rise after the dead time of about $20 \mathrm{sec}$ and became $43.5^{\circ} \mathrm{C}$ at its maximum and gradually fell to $42.5^{\circ} \mathrm{C}$. Then, the leaf temperature settled to $40^{\circ} \mathrm{C}$ within $12 \mathrm{~min}$. When the air humidity of $60 \%$ was increased to $80 \%$, the leaf temperature gradually rose and became $40.5^{\circ} \mathrm{C}$ at its maximum, while, the air temperature

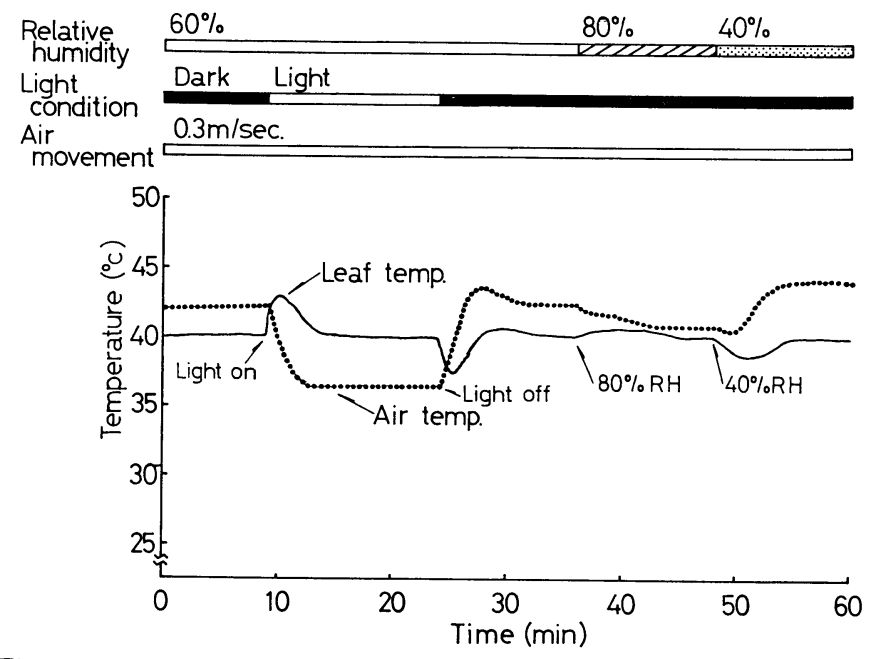

Fig. 5 Effects of light and air humidity on the control of leaf temperature at $40^{\circ} \mathrm{C}$ with an air velocity of $0.3 \mathrm{~m} / \mathrm{sec}$. 

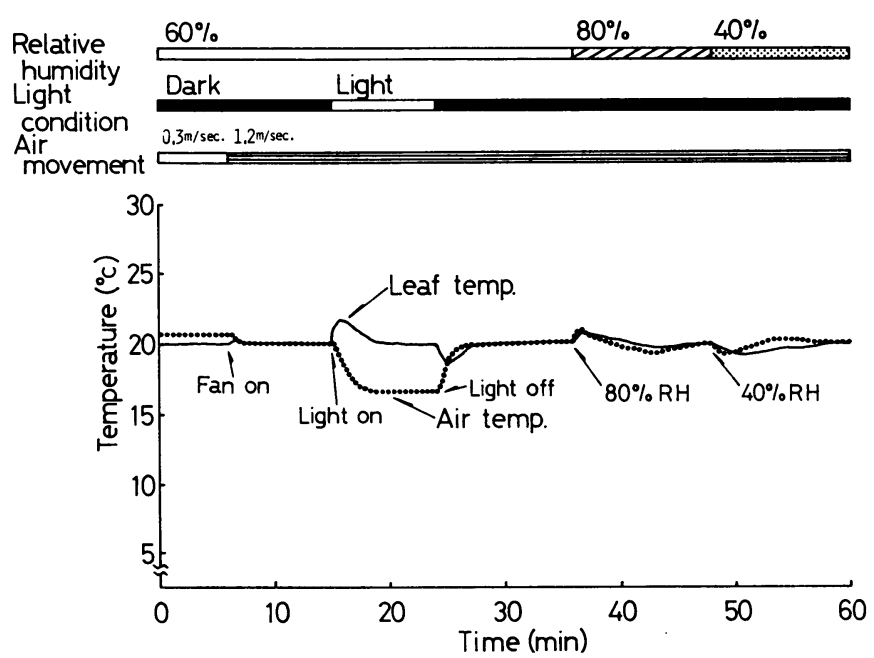

Fig. 6 Effects of light and air humidity on the control of leaf temperature at $20^{\circ} \mathrm{C}$ with an air movement of $1.2 \mathrm{~m} / \mathrm{sec}$.

fell to $40.7^{\circ} \mathrm{C}$. Then, the leaf temperature settled within $9 \mathrm{~min}$. When the air humidity of $80 \%$ was decreased to $40 \%$, the leaf temperature fell to $38.5^{\circ} \mathrm{C}$ at its minimum, while, the air temperature rose to $44^{\circ} \mathrm{C}$. After $5 \mathrm{~min}$, the leaf temperature settled, when, the air temperature was $43.5^{\circ} \mathrm{C}$.

Figure 6 shows the effects of light and air humidity on the leaf temperature controlled at $20^{\circ} \mathrm{C}$ when the air movement was increased to $1.2 \pm 0.2 \mathrm{~m} / \mathrm{sec}$. With an air movement of $0.3 \mathrm{~m} / \mathrm{sec}$, the leaf temperature was $20^{\circ} \mathrm{C}$, and the air temperature was $20.8^{\circ} \mathrm{C}$ in darkness. When the velocity of the air movement of $0.3 \mathrm{~m} / \mathrm{sec}$ was increased to $1.2 \mathrm{~m} / \mathrm{sec}$, the leaf temperature rose slightly, while, the air temperature fell to $20^{\circ} \mathrm{C}$. Then, the leaf temperature settled within $1 \mathrm{~min}$. Under this set of condition, the difference between the leaf and air temperatures was not observed. When the leaf was irradiated, the leaf temperature rose to $21.7^{\circ} \mathrm{C}$ at its maximum, while, the air temperature started to fall after the dead time of about $20 \mathrm{sec}$ and became $16.5^{\circ} \mathrm{C}$. In proportion to the air temperature fall, the leaf temperature fell and settled within $4 \mathrm{~min}$. When the irradiation was stopped, the leaf temperature fell to $18.5^{\circ} \mathrm{C}$ at its minimum, while, the air temperature started to rise after the dead time of about $20 \mathrm{sec}$ and became $20^{\circ} \mathrm{C}$. Then, the leaf temperature rose and settled at $20^{\circ} \mathrm{C}$ within $3 \mathrm{~min}$. When the air humidity of $60 \%$ was increased to $80 \%$, the air and leaf temperatures rose to $21^{\circ} \mathrm{C}$ and $20.8^{\circ} \mathrm{C}$, respectively. As mentioned above, this air temperature rise could be considered to be occurred by the steam supply to increase the air humidity. After $10 \mathrm{~min}$, the leaf temperature settled, when, the air temperature became $20^{\circ} \mathrm{C}$. When the air humidity of $80 \%$ was decreased to $40 \%$, the air and leaf temperatures fell to $19.2^{\circ} \mathrm{C}$. This air temperature fall would be caused by the evaporation of water in air. The air temperature became $20^{\circ} \mathrm{C}$ immediately and at the same time, the leaf temperature settled.

Figure 7 shows the effects of light and air humidity on the leaf temperature controlled at $30^{\circ} \mathrm{C}$ when the air movement was increased to $1.2 \mathrm{~m} / \mathrm{sec}$. In dark- 


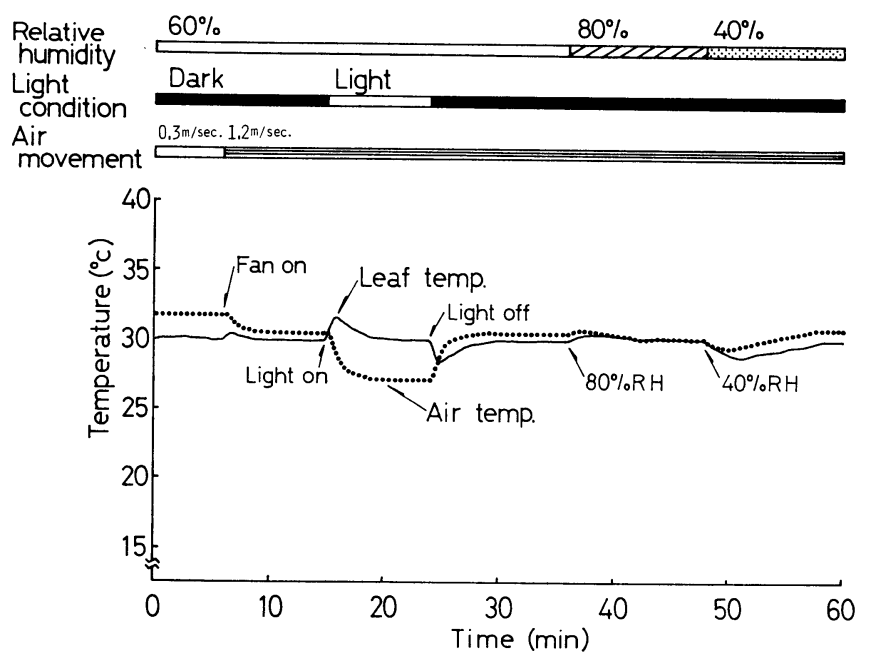

Fig. 7 Effects of light and air humidity on the control of leaf temperature at $30^{\circ} \mathrm{C}$ with an air movement of $1.2 \mathrm{~m} / \mathrm{sec}$.

ness, the leaf temperature was $30^{\circ} \mathrm{C}$, and air temperature was $31.7^{\circ} \mathrm{C}$ with an air movement of $0.3 \mathrm{~m} / \mathrm{sec}$ at air humidity of $60 \%$. When the air movement of 0.3 $\mathrm{m} / \mathrm{sec}$ was increased to $1.2 \mathrm{~m} / \mathrm{sec}$, the leaf temperature rose to $30.4^{\circ} \mathrm{C}$, while the air temperature started to fall after the dead time of about $20 \mathrm{sec}$ and became $30.5^{\circ} \mathrm{C}$. In proportion to the air temperature fall, the leaf temperature fell and settled, immediately. When the leaf was irradiated, the leaf temperature rose to $31.5^{\circ} \mathrm{C}$, while, the air temperature started to fall after the dead time of about $20 \mathrm{sec}$ and became $27.0^{\circ} \mathrm{C}$. In proportion to this air temperature fall, the leaf temperature fell and settled within $4 \mathrm{~min}$. When the irradiation was stopped, the leaf temperature fell to $28.5^{\circ} \mathrm{C}$, while, the air temperature started to rise after the dead time of about $20 \mathrm{sec}$ and became $30.5^{\circ} \mathrm{C}$. Then, the leaf temperature rose gradually and settled within $3 \mathrm{~min}$. When the air humidity of $60 \%$ was increased to $80 \%$, the leaf temperature became $30.5^{\circ} \mathrm{C}$ and settled, at the same time when the air temperature fell and became $30^{\circ} \mathrm{C}$. When the air humidity of $80 \%$ was decreased to $40 \%$, the leaf temperature fell and became $28.8^{\circ} \mathrm{C}$ at its minimum. The air temperature fell slightly in short time, thereafter it rose and became $30.7^{\circ} \mathrm{C}$. Then the air temperature settled within $5 \mathrm{~min}$.

Figure 8 shows the effects of light and air humidity on the leaf temperature controlled at $40^{\circ} \mathrm{C}$ when the air movement was increased to $1.2 \mathrm{~m} / \mathrm{sec}$. With an air movement of $0.3 \mathrm{~m} / \mathrm{sec}$, the leaf temperature was $40^{\circ} \mathrm{C}$ and the air temperature was $42.1^{\circ} \mathrm{C}$ in darkness. When the air movement of $0.3 \mathrm{~m} / \mathrm{sec}$ was increased to $1.2 \mathrm{~m} / \mathrm{sec}$, the leaf temperature rise to $40.8^{\circ} \mathrm{C}$, while, the air temperature started to fall after the dead time of about $20 \mathrm{sec}$ and became $40.6^{\circ} \mathrm{C}$. Then the leaf temperature fell immediately and settled. When the leaf was irradiated, the leaf temperature rose rapidly to $41.4^{\circ} \mathrm{C}$, while, the air temperature started to fall after the dead time of $20 \mathrm{sec}$ and became $37.8^{\circ} \mathrm{C}$. Then the leaf temperature fell gradually and settled within $9 \mathrm{~min}$. When the irradiation was stopped, the leaf temperature fell rapidly and became $38.5^{\circ} \mathrm{C}$ at its minimum, while, the air temper- 

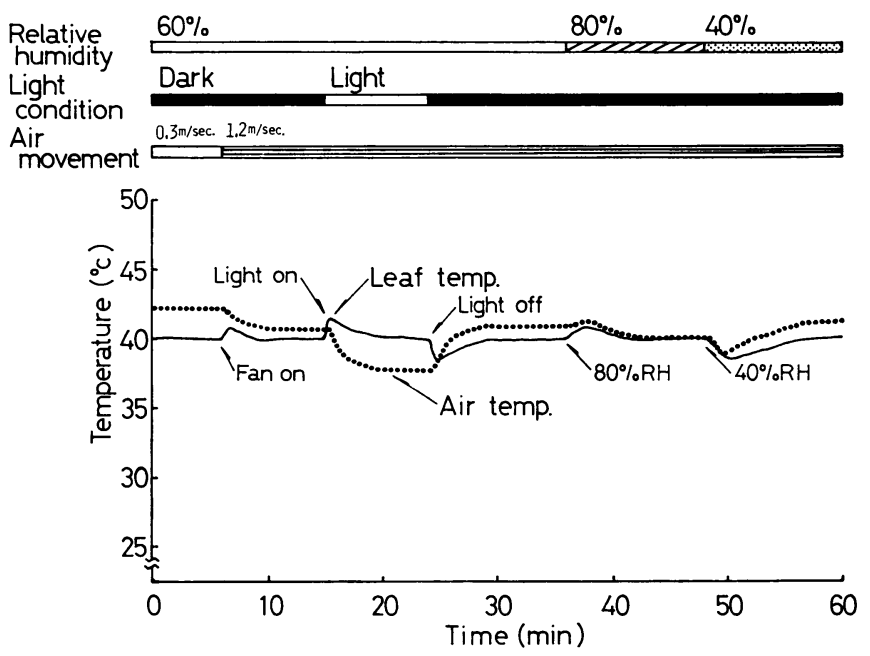

Fig. 8 Effects of light and air humidity on the control of leaf temperature at $40^{\circ} \mathrm{C}$ with an air movement of $1.2 \mathrm{~m} / \mathrm{sec}$.

ature started to rise after the dead time of about $20 \mathrm{sec}$ and became $40.9^{\circ} \mathrm{C}$. Then, the leaf temperature gradually rose and settled within $5 \mathrm{~min}$. When the air humidity of $60 \%$ was increased to $80 \%$, the leaf temperature rose to $40.8^{\circ} \mathrm{C}$, thereafter it gradually fell and settled, at the same time when the air temperature fell to $40^{\circ} \mathrm{C}$. There are no difference between the leaf and air temperatures under this condition. When the air humidity of $80 \%$ was decreased to $40 \%$, the leaf temperature fell to $38.8^{\circ} \mathrm{C}$ and the air temperature fell to $39^{\circ} \mathrm{C}$ in short time, but it started to rise and became $31.2^{\circ} \mathrm{C}$. The leaf temperature rose gradually and settled within $5 \mathrm{~min}$.

Thus, it is clear that light and air humidity affect the leaf temperature control as the disturbances: The irradiation disturbed the leaf temperature control much more under lower temperature condition than under higher temperature condition. While, the change of air humidity disturbed the leaf temperature much more under higher temperature condition than under lower temperature condition. The difference between the leaf and air temperatures was decreased, and the settling time was shortened by the increase in the air movement. In this system of leaf temperature control, the leaf temperature which was affected by these large disturbances could settled within 15 min under every condition of the constant-value control.

\section{REFERENCES}

1) Gates, D.M. 1964. Leaf temperature and transpiration. Agron. J. 56: 273-277.

2) NishiYAmA, I. 1972. Relation between rice leaf and ambient air temperatures in a phytotron. Environ. Control in Biol. 10: 7-11.

3) Matsui, T., H. Eguchi, Y. Hanami, S. Handa, and T. Terajima. 1971. A growth cabinet for the study on biotronics. I. Design and performance. Environ. Control in Biol. 9: 3746.

4) Matsui, T., and H. EgUCHI. 1971. Effects of environmental factors on leaf temperature in 
a temperature controlled room. Environ. Control in Biol. 8: 101-105.

5) MAtsui, T., and H. EGUCHI. 1972. Effects of environmental factors on leaf temperature in a temperature controlled room. II. Effect of air movement. Environ. Control in Biol. 10: $105-108$.

6) TAKECHI, O. 1968. Temperature and heat budget of plant leaf. Jour. Agric. Meteorology. Tokyo 24: 95-102.

7) TANner, C.B. 1963. Plant temperatures. Agron. J. 55: 210-211.

<和文抄録 $>$

\title{
葉温の Feedback 制御
}

\author{
松井健・江口弘美
}

九州大学生物環境調節センター

植物体温と空気温度との間には相当な差が認められ，とくに葉温は空気温度，空気湿度，光，風に著 しく複雑に影響されることはすでに知られている。本研究では，葉温を目標值として設定し，葉温のプ ログラムコントロールをおこなうために，グロースキャビネットにおいて葉温を feedback 信号として 用い，空気を熱伝達に用いる制御系を作成した。この葉温の feedback 制御系における葉温制御特性を 解析するために, この葉温制御に外乱として, 葉面への光照射, 空気湿度变動, 風速变動を与えた. そ の結果，次の点が明らかとなった。

1）プログラム制御における葉温のランプ応答は目標值に良好な追従を示した。その時の空気温度 は，葉温設定值 $10^{\circ} \mathrm{C}$ の時は葉温と同じであったが，葉温設定值が上るにしたがって空気温度は葉 温より高くなり，葉温設定值 $40^{\circ} \mathrm{C}$ では $43^{\circ} \mathrm{C}$ であった.

2）タングステンランプによって $31 \mathrm{~mW} / \mathrm{cm}^{2}$ の光照射を葉面に垂直におこなった場合，葉温は一時 的に上昇したが，空気温度の下降によって15分以内に整定された．光照射の外乱としての効果は低 温条件で大で，高温条件で小であった。

3）空気湿度を 60\% (RH) から $80 \%$ に，また $80 \%$ から $40 \%$ に，急速に变動させた場合，葉温 は一時的に変動したが 10 分以内に整定された．空気湿度変動の外乱としての効果は高温条件で大 で，低温条件で小であった。

4）風速増加は熱伝達速度を大にし，葉温制御系に光照射，空気湿度変動を外乱として与えた場合， 風速の増加によって，その整定時間は著しく短縮された。 